\title{
PENGARUH PERENCANAAN ANGGARAN TERHADAP PENYERAPAN ANGGARAN PADA DINAS PENATAAN RUANG KOTA BANDUNG
}

\author{
Engkus $^{1}$, Endang Hermawan ${ }^{2}$, Endah Dwi Rahmawati ${ }^{3}$ \\ ${ }^{1,2,3}$ UIN Sunan Gunung Djati Bandung \\ Email: engkus@uinsgd.ac.id
}

\begin{abstract}
Abstrak
Penelitian ini bertujuan untuk mengetahui seberapa besar pengaruh perencanaan anggaran terhadap penyerapan anggaran. Metode yang digunakan dalam penelitian ini adalah penelitian kuantitatif dengan pendekatan asosiatif. Teknik pengumpulan data melalui studi kepustakaan, observasi dan kuesioner. Angket disebarkan kepada 76 responden,dengan teknik analisis adalah koefisien regresi linier sederhana. Hasil penelitian ini terdapat pengaruh yang signifikan antara dimensi perencanaan anggaran dan penyerapan anggaran. Dengan pengujian dua sisi (signifikasi $=0,05$ ) hasil pengujian secara parsial (uji t) diperoleh $t_{\text {hitung }}>t_{\text {tabel }}(12,582>1,995)$. Pada uji koefisien regresi secara simultan (uji f) diperoleh hasil $\mathrm{f}_{\text {hitung }}>\mathrm{f}_{\text {tabel }}(158,296>3,09)$ dengan taraf signifikan $0,000<0,05$ maka Ha diterima, artinya secara simultan terdapat pengaruh yang signifikan antara perencanaan anggaran terhadap penyerapan anggaran. Sedangkan hasil perhitungan koefisien determinasi sebesar $68,1 \%$, maka besar pengaruh perencanaan anggaran terhadap panyerapan anggaran sebesar $68,1 \%$ dan sisanya sebesar 31,9\% dipengaruhi atau dijelaskan oleh variabel lain yang tidak diteliti oleh peneliti.
\end{abstract}

Kata Kunci: Perencanaan, Implementasi, Penyerapan Anggaran.

\begin{abstract}
This study aims to determine how much influence budget planning has on budget absorption. The method used in this research is quantitative research with an associative approach. Data collection techniques through literature study, observation and questionnaires. The questionnaire was distributed to 76 respondents, with the analysis technique is a simple linear regression coefficient. The results of this study have a significant influence between the dimensions of budget planning and budget absorption. With two-sided testing (significance = $0.05)$ the partial test results ( $t$ test) obtained $t$ count $>t$ table $(12.582>1.995)$. In the simultaneous regression coefficient test $(f$ test), the results of $f$ count $>f$ table $(158.296>$ 3.09) are obtained with a significant level of $0.000<0.05$, so Ha is accepted, meaning that simultaneously there is a significant influence between budget planning and budget absorption. While the calculation of the coefficient of determination is $68.1 \%$, the influence of budget planning on budget absorption is $68.1 \%$ and the remaining $31.9 \%$ is influenced or explained by other variables not examined by the researcher.
\end{abstract}

Keywords: Planning, Implementation, Budget Absorption.

\section{A. PENDAHULUAN}

Berdasarkan Undang-Undang Nomor 9 Tahun 1999 tentang Pemerintah Daerah bahwa penyelenggaraan Otonomi Daerah dipandang perlu untuk lebih menekankan pada 
prinsip-prinsip demokrasi, peran serta masyarakat, pemerataan dan keadilan, serta memperhatikan potensi dan keanekaragaman Daerah. Kemudian diganti menjadi UndangUndang Nomor 23 Tahun 2014 tentang Pemerintah Daerah dan yang terbaru Undang-Undang Nomor 9 Tahun 2015 tentang Pemerintah Daerah yang berisi bahwa untuk kesinambungan kepemimpinan di provinsi, kabupaten/kota diperlukan mekanisme peralihan kepemimpinan daerah di masa jabatannya yang demokratis untuk dapat menjamin pembangunan dan pelayanan kepada masyarakat (Presiden RI, 2015).

Penyerahan segala urusan pemerintah oleh Pemerintah Pusat kepada daerah dalam mengatur dan mengurus sendiri kepentingan masyarakat daerah nya masing-masing (Engkus, 2013). Hal ini diharapkan dapat meningkatkan keberhasilan suatu daerah. Maju tidaknya suatu daerah dapat dilakukan dengan cara meningkatkan kesejahteraan masyarakat dan menciptakan manajemen keuangan yang baik (Engkus, 2018). Penyerapan anggaran pada akhir-akhir ini menjadi sorotan di berbagai media sehubungan menunjukkan fenomena yang kurang optimal dilihat dari kinerja serapan belanja anggaran publik.

Belanja pemerintah dinilai masih lambat. Ini dibuktikan dengan masih kecilnya angka penyerapan anggaran di enam sektor utama Pemulihan Ekonomi Nasional (PEN). Sektor kesehatan masih menyerap 7,93 persen, perlindungan sosial 42,31 persen, Sektoral dan Pemda 8,01\%, UMKM 26,33 persen, Pembiayaan Korporasi 0 persen, dan Insentif Usaha 13,43 persen. Dalam situasi ini, Pemerintah, sebagaimana disampaikan oleh Wamenkeu, ingin menyerap seluruh defisit yang disiapkan, (Wakil Menteri Keuangan Suahasil Nazara, 2020) padahal belanja pemerintah sebagai penggerak ekonomi, sebagaimana disampaikan wapres RI. "Yang bisa menggerakkan ekonomi adalah belanja pemerintah," ujar Wapres Ma'ruf Amin (Wapres RI, 2020).

Berdasarkan Peraturan Pemerintah Nomor 58 Tahun 2005 tentang Pengelolaan Keuangan Daerah. Dalam hal ini pemerintah daerah diberi kebebasan dalam mengatur dan mengurus urusan pemerintahan daerah untuk mewujudkan pembangunan yang merata dan mensejahterakan masyarakat Oleh karena itu pengelolaan keuangan yang profesional dan transparan sangat penting dalam memberikan pelayanan kepada masyarakat (Presiden RI, 2005). Pengelolaan keuangan daerah di Kota Bandung diatur dalam Peraturan Daerah Kota Bandung Nomor 07 tahun 2016 tentang Pokok-Pokok Pengelolaan Keuangan Daerah. Setelah pemerintah daerah diberi wewenang untuk mengatur dan mengurus sendiri urusan pemerintahannya, aparatur pemerintah daerah mendapat sorotan tajam dari masyarakat khususnya mengenai keuangan daerah (Wali Kota Bandung, 2016). 
Dalam mencapai keberhasilannya, pemerintah daerah perlu membuat suatu perencanaan untuk menentukan program dan kegiatan apa saja yang akan dicapai dalam jangka pendek maupun jangka panjang. Pemerintah daerah akan mendapatkan Anggaran Pendapatan dan Belanjaan Daerah (APBD) sebagai sumber keuangan untuk mendanai berbagai program dan kegiatan yang telah direncanakan. Melalui laporan keuangan yang terdapat dalam suatu lembaga/organisasi pemerintah, akan dilihat apakah anggaran telah terserap dengan baik terhadap perencanaan program dan kegiatan yang telah disusun sebelumnya.

Besarnya rasio efektivitas menggambarkan kemampuan daerah yang semakin baik. Pada Dinas Penataan Ruang Kota Bandung adanya ketidaksesuaian antara penyerapan anggaran dengan perencanaan anggaran pada tahun 2013-2017 yang tidak mencapai persentase yang telah ditetapkan Peraturan Menteri Keuangan Republik Indonesia Nomor 158/PMK.02/2014 Tentang Tata Cara Pemberian Penghargaan Dan Pengenaan Sanksi Atas Pelaksanaan Anggaran Belanja Kementerian Negara/Lembaga yaitu sebesar 95\% (Presiden RI, 2014). Hal ini dapat dilihat pada tabel 1, sebagai berikut:

Tabel 1 Laporan Realisasi Anggaran Dinas Penataan Ruang Kota Bandung

\begin{tabular}{|c|c|c|c|c|}
\hline Tahun & Anggaran (Rp) & Realisasi (Rp) & Presentase & Keterangan \\
\hline 2013 & 358.135 .409 .363 & 304.519 .185 .472 & $85,03 \%$ & Baik \\
\hline 2014 & 250.174 .347 .706 & 114.429 .154 .331 & $45,74 \%$ & Kurang \\
\hline 2015 & 190.751 .499 .959 & 131.790 .652 .908 & $69,09 \%$ & Cukup \\
\hline 2016 & 276.235 .582 .052 & 167.475 .695 .540 & $64,53 \%$ & Cukup \\
\hline 2017 & 108.275 .653 .372 & 71.235 .712 .721 & $60,63 \%$ & Cukup \\
\hline
\end{tabular}

Sumber: Dinas Penataan Ruang Kota Bandung (diolah peneliti), 2019.

Presentase pada Dinas Penataan Ruang Kota Bandung tahun 2013-2017 tidak mencapai 95\%. Berdasarkan tabel di atas, presentase terbesar pada tahun 2013 sebesar $85 \%$ dan dikatakan baik. Sedangkan pada tahun 2015-2017 dikatakan cukup. Dan presentase penyerapan anggaran terendah yaitu pada tahun 2014 yang hanya mencapai 45,74\% dan dikatakan tidak efektif. Hal ini dapat diartikan bahwa Dinas Penataan Ruang Kota Bandung mengalami kelebihan anggaran pada tahun 2013-2017.

Penelitian ini bertujuan untuk mengetahui seberapa besar pengaruh perencanaan anggaran terhadap penyerapan anggaran. Selain itu untuk mengetahui implementasi kebijakan di level pemerintahan garda terdepan/street level. (Engkus E, 2020). Diharapkan hasil penelitian ini bermanfaat bagi pemerintah baik pusat maupun daerah yang dalam dekade terakhir tentang penyerapan anggaran menjadi problem yang sering terjadi. 


\section{B. TINJAUAN PUSTAKA}

Perencanaan menurut (Mardiasmo, 2009) adalah cara organisasi menetapkan tujuan dan sasaran organisasi. Perencanaan meliputi aktivitas yang sifatnya strategik, taktis dan melibatkan aspek operasional. Perencanaan dalam organisasi sangat penting dilakukan untuk mengantisipasi keadaan di masa yang akan datang. Bagi tiap-tiap organisasi, sistem perencanaan berbeda-beda tergantung pada tingkat ketidakpastian dan kestabilan lingkungan yang mempengaruhi. Semakin tinggi tingkat ketidakpastian dan ketidakstabilan lingkungan yang dihadapi organisasi, maka kejadian ekonomi yang akan datang dikaitkan dengan keadaan ekonomi dan politik saat ini.

Perencanaan secara konvensional didefinisikan sebagai kegiatan yang dilakukan untuk masa mendatang yang lebih baik dengan memperhatikan keadaan sekarang maupun sebelumnya. Menurut Robbins \& Coulter (dalam Bastian, 2010), perencanaan (planning) merupakan proses yang dimulai dari penetapan tujuan organisasi, yaitu menentukan strategi untuk pencapaian tersebut secara menyeluruh serta merumuskan sistem perencanaan yang menyeluruh untuk mengintegrasikan dan mengoordinasikan seluruh pekerjaan organisasi, hingga terciptanya tujuan organisasi.

Menurut Fattah (2006), perencanaan anggaran adalah suatu rencana operasi dari suatu kegiatan yang mengandung perinci pengeluaran biaya untuk satu periode tertentu agar dapat dimanfaatkan secara optimal untuk menunjang tercapainya tujuan.

Menurut (Pamungkas, 2013) untuk dapat mengendalikan tingkat efisiensi dan efektifitas anggaran, maka dalam perencanaan anggaran perlu diperhatikan:

1. Penetapan secara jelas tujuan dan sasaran, hasil dan manfaat, serta indikator kinerja yang ingin dicapai.

2. Penetapan prioritas kegiatan dan penghitungan beban kerja, serta penetapan harga satuan yang rasional.

Halim (2014), menjelaskan bahwa penyerapan anggaran adalah pencapaian dari suatu estimasi yang hendak dicapai selama periode waktu tertentu dipandang pada suatu saat tertentu (realisasi dari anggaran). Secara lebih mudah orang awam menyebutnya pencairan anggaran. Oleh karena yang diamati adalah organisasi sektor publik atau entitas pemerintahan, maka penyerapan anggaran disini dapat diartikan sebagai pencairan atau realisasi anggaran sesuai yang tercantum dalam Laporan Realisasi Anggaran (LRA) pada saat periode tertentu.

Adapun menurut Kuncoro (2013), penyerapan anggaran merupakan salah satu tahapan dari siklus anggaran yang dimulai dari perencanaan anggaran, penetapan dan 
pengesahan anggaran oleh Dewan Perwakilan Rakyat (DPR), penyerapan anggaran, pengawasan anggaran, dan pertanggungjawaban penyerapan anggaran.

Adapun faktor-faktor yang mempengaruhi rendahnya penyerapan anggaran menurut (Halim, 2014) adalah sebagai berikut:

1. Lemahnya perencanaan anggaran. Rendahnya daya serap anggaran mencerminkan pelakasanaan program pemerintah yang lemah dan kurang matang. Adanya revisirevisi menyebabkan kegiatan sulit atau terlambat dieksekusi.

2. Lamanya proses pembahasan anggaran. Seharusnya pembahasan anggaran sudah final sampai rincian alokasi anggaran sampai dengan bulan Desember, sehingga bulan Januari tahun berikutnya pemerintahan daerah sudah siap melaksanakan program yang telah disepakati. Tarik ulur ini efeknya juga menjadikan kegiatan yang diusulkan menjadi tidak tepat sasaram.

3. Lambannya proses tender. Beberapa peraturan yang berkaitan dengan barang dan jasa perlu disosialisasikan lebih luas.

4. Ketakutan menggunakan anggaran. Sikap ketakutan pemerintah yang berlebihan menyebabkan alokasi pendanaan untuk pembangunan menjadi stagnan.

\begin{tabular}{|c|c|}
\hline $\begin{array}{c}\text { Perencanaan Anggaran (X) } \\
\text { Pamungkas (2013:19) }\end{array}$ & $\begin{array}{c}\text { Penyerapan Anggaran (Y) } \\
\text { Halim (2014:91) }\end{array}$ \\
\hline $\begin{array}{l}\text { a. Penetapan secara jelas tujuan } \\
\text { dan sasaran, hasil dan manfaat, } \\
\text { serta indikator kinerja yang } \\
\text { ingin dicapai. } \\
\text { b. Penetapan prioritas kegiatan dan } \\
\text { perhitungan beban kerja serta } \\
\text { penetapan harga satuan yang } \\
\text { rasional. }\end{array}$ & $\begin{array}{ll}\text { a. Lemahnya perencanaan } \\
\text { anggaran } \\
\text { b. Lamanya proses } \\
\text { anggaran } \\
\text { c. Lambannya proses tender } \\
\text { d. Ketakutan menggunakan } \\
\text { anggaran }\end{array}$ \\
\hline
\end{tabular}

\section{Gambar 1 Kerangka Pemikiran}

\section{METODE PENELITIAN}

Metode penelitian yang digunakan adalah metode penelitian kuantitatif. Menurut Darmawan (2016) penelitian kuantitatif memusatkan perhatian pada gejala-gejala yang mempunyai karakteristik di dalam kehidupan manusia yang dinamakannya sebagai variabel. Dalam pendekatan kuantitatif, hakikat hubungan di antara variabel-variabel dianalisis dengan menggunakan teori yang objektif.

Penelitian ini merupakan penelitian eksplanatori, yang bertujuan untuk menjelaskan hubungan antara dua variabel atau lebih gejala atau variabel. Tipe penelitian eksplanatori 
yang digunakan peneliti adalah penelitian assosiasi atau korelasional. Anggara (2016), menjelaskan penelitian assosiatif adalah penelitian yang dilakukan dengan tujuan untuk melihat hubungan antarvariabel atau pengaruh suatu variabel terhadap variabel lainnya. Di dalam penelitian ini, peneliti menggunakan penelitian eksplanatori dengan pendekatan kuantitatif yang bertujuan untuk mengetahui Pengaruh Perencanaan Anggaran terhadap Penyerapan Anggaran pada Dinas Penataan Ruang Kota Bandung.

\section{HASIL DAN PEMBAHASAN}

Menurut Fattah, (2006) Perencanaan anggaran adalah suatu rencana operasi dari suatu kegiatan yang mengandung perinci pengeluaran biaya untuk satu periode tertentu agar dapat dimanfaatkan secara optimal untuk menunjang tercapainya tujuan. Dalam mengukur dimensi perencanaan anggaran, peneliti menggunakan skala likert. Menurut Silalahi Ulbert (2009), Skala likert adalah teknik penskalaan yang banyak digunakan terutama untuk mengukur sikap, pendapat atau persepsi seseorang tentang dirinya atau kelompoknya atau sekelompok orang berhubungan dengan suatu hal. Skala ini sering disebut sebagai summated scale yang berisi sejumlah pernyataan dengan kategori responden dan kemudian nilai/skor seseorang pada skala dihitung dengan menjumlahkan jumlah tanggapan yang ia berikan. Perencanaan anggaran memiliki dua dimensi yaitu penetapan secara jelas tujuan dan sasaran, hasil dan manfaat, serta indikator kinerja yang ingin dicapai dan penetapan prioritas kegiatan dan penghitungan beban kerja, serta penetapan harga satuan yang rasional (Ishak, Maolani, \& Engkus, 2017).

Berdasarkan hasil akumulasi (hasil uji statistik) bahwa perencanaan anggaran memperoleh nilai sebesar 5697 yang terletak diantara rentang 4909,6 dan 6064,8. Dengan demikian dapat diketahui bahwa perencanaan anggaran berada pada kategori tinggi. Sedangkan pada nilai persentase, akumulasi perencanaan anggaran mendapatkan persentase sebesar 79,1\% yang terletak diantara rentang $68 \%$ dan $84 \%$. Dimana hasil tersebut termasuk kedalam kategori efektif. Sehingga dapat disimpulkan bahwa perencanaan anggaran di Dinas Penataan Ruang Kota Bandung sudah berlangsung dengan sangat baik.

Halim (2014), menjelaskan bahwa penyerapan anggaran adalah pencapaian dari suatu estimasi yang hendak dicapai selama periode waktu tertentu dipandang pada suatu saat tertentu (realisasi dari anggaran). Secara lebih mudah orang awam menyebutnya pencairan anggaran. Oleh karena yang diamati adalah organisasi sektor publik atau entitas pemerintahan, maka penyerapan anggaran disini dapat diartikan sebagai pencairan atau 
realisasi anggaran sesuai yang tercantum dalam Laporan Realisasi Anggaran (LRA) pada saat periode tertentu.

Dalam mengukur dimensi perencanaan anggaran, peneliti menggunakan skala likert. Menurut Silalahi (2009), Skala likert adalah teknik penskalaan yang banyak digunakan terutama untuk mengukur sikap, pendapat atau persepsi seseorang tentang dirinya atau kelompoknya atau sekelompok orang berhubungan dengan suatu hal. Skala ini sering disebut sebagai summated scale yang berisi sejumlah pernyataan dengan kategori responden dan kemudian nilai/skor seseorang pada skala dihitung dengan menjumlahkan jumlah tanggapan yang ia berikan. Penyerapan anggaran memiliki empat dimensi yaitu lemahnya perencanaan anggaran, lemahnya proses pembahasan anggaran, lambannya proses tender, dan ketakutan menggunakan anggaran.

Berdasarkan hasil akumulasi (hasil uji statistik) dan garis interval di atas dapat diketahui bahwa penyerapan anggaran memperoleh nilai sebesar 4025 yang terletak diantara rentang 3617,6 dan 4468,8. Dengan demikian dapat diketahui bahwa penyerapaan anggaran berada pada kategori tinggi.. Sedangkan pada nilai persentase, akumulasi perencanaan anggaran mendapatkan persentase sebesar 75,6\% yang terletak diantara rentang $62 \%$ dan 81\%. Dimana hasil tersebut termasuk kedalam kategori efektif. Sehingga dapat disimpulkan bahwa penyerapan anggaran di Dinas Penataan Ruang Kota Bandung rendah, karena dimensi yang diteliti menunjukan kategori tinggi.

Validitas merupakan ketepatan dan kecermatan suatu alat ukur dalam melakukan fungsi ukurnya. Instrumen penelitian yang valid dapat diartikan bahwa alat ukur yang digunakan untuk mengukur data itu valid. Valid berarti instrumen tersebut dapat digunakan untuk mengukur apa yang seharusnya diukur. Pengujian validitas dilakukan dengan melakukan uji dua sisi dengan taraf signifikansi 0,05. Dari hasil analisis uji validitas didapatkan nilai korelasi antar skor item dengan skor total. Nilai ini kemudian dibandingkan dengan nilai $r_{\text {tabel }}, r_{\text {tabel }}$ dicari pada signifikansi 0,05 dengan uji dua sisi dan jumlah data $n=76$, maka didapat $r$ tabel sebesar 0,220. Berdasarkan pada tabel 4.9 didapatkan nilai korelasi itemitem yang nilainya lebih dari 0,220 sehingga dapat disimpulkan bahwa butir instrumen penelitian Perencanaan Anggaran (X), dan Penyerapan Anggaran (Y) dinyatakan valid.

Uji reliabilitas digunakan untuk mengetahui konsistensi alat ukur, apakah alat ukur yang digunakan memiliki keandalan dan tetap konsisten jika pengukuran tersebut diulang. Dari hasil uji reliabilitas menggunakan pengolahan SPSS 22, maka diperoleh nilai alpha sebesar 0,927. Karena nilai Cronbach Alpha lebih besar dari 0,60 (0,956>0,60), kemudian jika dibandingkan dengan nilai $\mathrm{r}$ tabel dengan $\mathrm{n}=76$ pada distribusi nilai $\mathrm{r}$ tabel pada 
signifikasi 0,05 maka diperoleh $\mathrm{r}$ tabel sebesar 0,220 (0,956 > 0,220). Jadi dapat disimpulkan bahwa variabel perencanaan anggaran dan penyerapan anggaran dapat dikatakan reliabel dan dapat digunakan untuk pengujian selanjutnya.

\section{E. KESIMPULAN}

Berdasarkan hasil pengujian hipotesis dapat disimpulkan bahwa terdapat pengaruh yang signifikan antara perencanaan anggaran terhadap penyerapan anggaran pada Dinas Penataan Ruang Kota Bandung, baik secara parsial maupun secara simultan. Berdasarkan perhitungan koefisien determinasi, persentase kontribui pengaruh perencanaan anggaran terhadap variabel penyerapan anggaran sebesar $68,1 \%$. Sedangkan sisanya sebesar $31,9 \%$ dipengaruhi atau dijelaskan oleh variabel lain (epsilon) yang tidak diteliti oleh peneliti.

\section{DAFTAR PUSTAKA}

Anggara, S. (2016). Administrasi Keuangan Negara. Bandung: Pustaka Setia.

Bastian, I. (2010). Akuntansi Sektor Publik: Suatu Pengantar. Jakarta: Erlangga.

Darmawan, D. (2016). Metode Penelitian Kuantitatif. Bandung: Remaja Rosdakarya.

Engkus, E. (2018). Perspektif Administrasi Pembangunan: Menuju Ke Arah Konvergentif. JISPO: Jurnal Ilmu Sosial Dan Ilmu Politik, 8(2), 190-201.

Engkus E. (2013). Desentralisasi (Teori yang Baik dengan Praktek yang buruk). Desentralisasi (Teori yang Baik Dengan Praktek yang buruk). JISPO: Jurnal Ilmu Sosial Dan Ilmu Politik, 1 (4), 1-16.

Engkus E. (2020). Komunikasi Kebijakan Bantuan Pangan Nontunai melalui E-Warong. Jurnal Penelitian Komunikasi., 23(1), 47-60.

Fattah, N. (2006). Landasan Mnajaemen Pendidikan. Bandung: Remaja Rosdakarya.

Halim, A. (2014). Manajemen Keuangan Sektor Publik. Jakarta: Salemba Empat.

Ishak, D., Maolani, D. Y., \& Engkus, E. (2017). Konsep Kinerja Dalam Studi Organisasi Publik. JISPO Jurnal Ilmu Sosial Dan Ilmu Politik, 7(2), 101-120.

Kuncoro, M. (2013). Metode Riset untuk Bisnis dan Ekonomi. Jakarta: Erlangga.

Mardiasmo. (2009). Akuntansi Sektor Publik. Yogyakarta: Andi.

Pamungkas, B. (2013). Dasar-dasar Manajemen Keuangan. Bogor: Kesatuan Press.

Peraturan Daerah Kota Bandung Nomor 07 tahun 2016 tentang Pokok-Pokok Pengelolaan Keuangan Daerah.

Peraturan Pemerintah Nomor 58 Tahun 2005 tentang Pengelolaan Keuangan Daerah.

Peraturan Menteri Keuangan Republik Indonesia Nomor 158 Tahun 2014 Tentang Tata Cara Pemberian Penghargaan dan Pengenaan Sanksi Atas Pelaksanaan Anggaran Belanja Kementerian Negara/Lembaga. 
Purnamasari, D. M. (2020). Wapres Soroti Penyerapan Anggaran yang Rendah di Tengah Pandemi. Diakses dari https://nasional.kompas.com/read/2020/08/13/16411931/wa.

Undang-Undang Nomor 9 Tahun 2015 tentang Pemerintah Daerah. Presiden Republik Indonesia.

Silalahi, U. (2009). Metode Penelitian Sosial. Bandung. Bandung: Refika Aditama.

Supriyatna, I. (2020). 6 Sektor Penyerapan Anggaran Program PEN Masih Rendah. Diakses dari https://www.suara.com/bisnis/2020/08/12/151030/6-sektor-penyerapan-anggaranprogram-pen-masih-rendah. 